\title{
Microscale distribution of oxygen and nitrate in sediment inhabited by Nereis diversicolor: spatial patterns and estimated reaction rates
}

\author{
Ole Ilsøe Nielsen ${ }^{1,3, *}$, Britta Gribsholt ${ }^{1,4}$, Erik Kristensen ${ }^{1}$, Niels Peter Revsbech ${ }^{2}$ \\ ${ }^{1}$ Institute of Biology, University of Southern Denmark, 5230 Odense M, Denmark \\ ${ }^{2}$ Institute for Biological Sciences, Department of Microbial Ecology, University of Aarhus, 8000 Aarhus C, Denmark \\ ${ }^{3}$ Present address: Florida Atlantic University, Biological Science Department, Boca Raton, 33431 Florida, USA \\ ${ }^{4}$ Present address: Netherlands Institute of Ecology, Centre for Estuarine and Coastal Ecology, PO Box 140, 4400 AC Yerseke, \\ The Netherlands
}

\begin{abstract}
Profiles of oxygen and nitrate were measured with microsensors in sediment surrounding burrow structures of the polychaete Nereis diversicolor in a shallow mudflat in Limfjorden, Denmark. Rates and spatial distribution of reactions involving oxygen and nitrate (oxygen consumption, nitrification and nitrate reduction) in the vicinity of burrow structures and surface sediment were calculated and identified from concentration profiles. The burrow walls of the natural N. diversicolor population increased the surface area of the sediment-water interface several-fold and introduced oxic microniches with high metabolic activity into otherwise anoxic sediment. Nitrification and nitrate reduction were spatially separated processes, with nitrification restricted to the 0.9 to $1.5 \mathrm{~mm}$ thick oxic zone and nitrate-reduction occurring as a strictly anaerobic process in the nitratecontaining layers next to the oxic zone. At a density of 2560 individuals $\mathrm{m}^{-2}$, burrow walls of $N$. diversicolor account for 12 to $40 \%$ of bulk sediment oxygen uptake and 50 to $77 \%$ and 58 to $82 \%$ of bulk nitrification and nitrate reduction, respectively. Thus, burrow structures of macro-infauna are potentially a major sediment compartment involved in nitrogen cycling and may promote loss of bioavailable nitrogen from the sediment.
\end{abstract}

KEY WORDS: $\mathrm{NO}_{3}{ }^{-} / \mathrm{NO}_{2}{ }^{-}$biosensor $\cdot$ Nitrogen cycling $\cdot$ Sediments $\cdot$ Bioturbation $\cdot$ Nereis diversicolor $\cdot$ Burrow walls

\section{INTRODUCTION}

Nitrogen cycling in sediments has been studied intensively during recent decades, and several approaches have been used to quantify nitrification and denitrification/nitrate reduction. These include mass balance (Lomstein et al. 1998), inhibition techniques (Ormeland \& Capone 1988), diagenetic modeling (Aller 1988), isotope techniques (Koike \& Hattori 1978, Nielsen 1992) and microsensors (Binnerup et al. 1992, Jensen et al. 1993, Lorenzen et al. 1998). It is now widely recognized that ammonium oxidation by nitrifying bacteria is crucial in generating nitrate for anaerobic denitrification, leading to loss of nitrogen to the atmosphere. It was realized early that the activity of burrowing macrofauna significantly enhanced nitrogen cycling in sediments by extending the oxic sediment-water interface into otherwise anoxic sediment (Henriksen et al. 1980). Irrespective of approach, animal species, location, and sediment type, most studies have revealed that burrow structures increase ammonium efflux from the sediment and increase nitrification as well as denitrification and nitrate uptake by the sediment (Henriksen et al. 1980, Kristensen et al. 1985, Pelegrí et al. 1994, Mayer et al. 1995, Pelegrí \& Blackburn 1995, Svensson \& Leonardson 1996, Gilbert et al. 1998). Animal density, size, and irrigation rates determine the degree to which the processes are stim- 
ulated, and species with high irrigation rates (e.g. Nereis diversicolor and Corophium volutator) have the most pronounced impact. Introduction of the isotope pairing technique (Nielsen 1992) further revealed that coupled nitrification/denitrification processes in burrows are stimulated in excess of what is predicted by assuming a simple extension of the sediment-water interface, probably due to temporally and spatially decreased diffusion distances in the burrow wall (Pelegri \& Blackburn 1995, Svensson \& Leonhardson 1996).

Burrow structures are often considered a physical and chemical extension of the sediment surface with compressed solute and reaction contours (Aller 1988). Although they are known as biogeochemical hot-spots with high organic loading, bacterial numbers, and activity (Kristensen 1988, Reichardt 1988, Hansen et al. 1996, Phillips \& Lovell 1999), relatively few studies have quantified and located biogeochemical reactions in the vicinity of the infaunal burrows. Direct measurements in the sediment immediately surrounding burrow structures have shown that this unique environment increases oxygen consumption (Binnerup et al. 1992), hampers sulfate reduction rates (Gribsholt et al. 2003, Nielsen et al. 2003) and increases potential nitrification and denitrification (Kristensen 1985, Mayer et al. 1995) compared to the surrounding sediment. In the past, nitrification denitrification processes in sediment surrounding burrow structures were measured from coarsely dissected burrows (low resolution) followed by slurry incubation (Kristensen 1985, Mayer et al. 1995) or by modeling similar coarse profiles of nitrate (Aller 1988). The development and introduction of $\mathrm{NO}_{3}{ }^{-} / \mathrm{NO}_{2}{ }^{-}$biosensors (Larsen et al. 1997) has made it possible to obtain high-resolution ( $\mu \mathrm{m}$-scale) profiles in sediments so that nitrification/nitrate reduction rates can be determined via diffusion-reaction modeling without the limitations and disadvantages associated with slurry experiments. These biosensors have proved excellent for measurements in marine surface sediments and freshwater microalgal biofilms (Larsen et al. 1997, Lorenzen et al. 1998), and are potentially a very powerful tool for studying nitrification and denitrification in stratified microbial communities.

The aim of the present study was to resolve the radial $\mathrm{O}_{2}$ and $\mathrm{NO}_{3}^{-}$distribution around burrows of Nereis diversicolor in a shallow Danish Fjord by the use of microsensors and to quantify nitrification/nitrate reduction processes associated with burrow walls. Oxygen consumption, net nitrification, and nitrate reduction were calculated from the measured $\mathrm{O}_{2}$ and $\mathrm{NO}_{3}{ }^{-}$profiles using a diffusion-reaction model. The contribution of nitrification/nitrate reduction around burrow walls to total sediment nitrification/nitrate reduction was evaluated and related to total sediment oxygen consumption.

\section{MATERIALS AND METHODS}

Sampling location and sediment handling. Sediment cores were collected in May and September 2000 from a shallow mud flat at Aggersund (Limfjorden, Denmark). The sampling site was located next to a small freshwater outlet and was permanently watercovered, with a salinity of about 20 ppt during sampling periods. No rooted plants were observed at the location, and bottom-dwellers such as the polychaete Nereis diversicolor and the crustacean Corophium volutator dominated the infaunal community.

Undisturbed sediment cores were sampled with transparent acrylic core tubes (8 $\mathrm{cm}$ inner diameter) on both sampling occasions. After return to the laboratory, sediment cores were acclimatized for at least $24 \mathrm{~h}$ at $15^{\circ} \mathrm{C}$ before further handling. Profile measurements were conducted on selected individual burrows $\left(\mathrm{O}_{2}\right.$ and $\mathrm{NO}_{3}{ }^{-} / \mathrm{NO}_{2}{ }^{-}$) from cores on both sampling occasions, whereas whole-core flux measurements were conducted only on sediment cores sampled in September 2000 .

Radial $\mathrm{O}_{2}$ and $\mathrm{NO}_{3}^{-}$profiles. Profiles of $\mathrm{O}_{2}$ and $\mathrm{NO}_{3}{ }^{-} / \mathrm{NO}_{2}{ }^{-}$were obtained vertically at the sediment surface (September only) and radially in sediment surrounding Nereis diversicolor (on both occasions) (Fig. 1A). To obtain radial profiles, sediment cores containing $N$. diversicolor were gently split to expose the burrow surface (Fig. 1B). Individual burrows walls and the surrounding sediment were positioned in plastic trays and placed in seawater from the sampling location prior to measurement. Vertical profiles were obtained from intact cores.

In May 2000, burrow walls received 1 of 3 treatments: (1) $\mathrm{NH}_{4}{ }^{+}$-enriched seawater to a concentration of $100 \mu \mathrm{M}$, (2) $\mathrm{NH}_{4}{ }^{+}$-enriched seawater $(100 \mu \mathrm{M})$ saturated with acetylene (20 Pa), and (3) unamended seawater. Radial burrow profiles of $\mathrm{O}_{2}$ and $\mathrm{NO}_{3}{ }^{-}$were measured from $0 \mathrm{~cm}$ to approximately $10 \mathrm{~cm}$ along the burrow shaft. The low concentration of acetylene in Treatment 2 was intended to inhibit nitrification activity without affecting denitrification (Klemedtsson et al. 1988). In September 2000, only $100 \mu \mathrm{M} \mathrm{NH}_{4}{ }^{+}$-amended seawater was used, as the nitrification rates under natural ammonium concentrations were too slow to measure. Radial burrow profiles of $\mathrm{O}_{2}$ and $\mathrm{NO}_{3}{ }^{-}$were measured at 3 vertical depth intervals $(0-3,3-6$, and $6-9 \mathrm{~cm})$ along the burrow shaft to determine whether depth in the sediment was important. In addition, vertical profiles were obtained from the sediment surface to compare rates at the surface with rates in the burrow wall.

Radial $\mathrm{O}_{2}$ profiles were measured by gently introducing a Clark type microelectrode (10 $\mu \mathrm{m}$ tip, lower detection limit $0.5 \mu \mathrm{M}$ ) (Revsbech 1989) vertically into the exposed burrow wall in steps of $100 \mu \mathrm{m}$. The elec- 
trode was held by a micromanipulator and connected to a picoammeter and strip-chart recorder. The electrode was calibrated by a 2-point calibration prior to measurements (i.e. in fully $\mathrm{O}_{2}$-saturated seawater of known temperature and salinity and by introducing the electrode into anoxic sediment).

Radial $\mathrm{NO}_{3}{ }^{-}$profiles were measured on the same burrows, and in the vicinity of the spot at which $\mathrm{O}_{2}$ profiles were obtained by a $\mathrm{NO}_{3}{ }^{-} / \mathrm{NO}_{2}{ }^{-}$biosensor (tip width of $35 \mu \mathrm{m}$, lower detection limit $0.5 \mu \mathrm{M}$ ) that had been pre-incubated for $1 \mathrm{~d}$ (Larsen et al. 1997) and calibrated by a 4-point calibration in water of known $\mathrm{NO}_{3}{ }^{-}$ concentration prior to measurements. The sensor was positioned just above the exposed burrow wall surface and was introduced vertically into the sediment in 100 to $250 \mu \mathrm{m}$ steps using a micromanipulator. The measured signals were amplified by a picoammeter and recorded on a strip-chart recorder. The profiles were obtained within approximately $30 \mathrm{~min}$ after burrow wall exposure. Vertical $\mathrm{NO}_{3}^{-}$profiles were obtained using the same biosensor for subsamples of surface sediment from undisturbed cores. Because $\mathrm{NO}_{2}^{-}$usually accounts for only a minor fraction of total $\mathrm{NO}_{3}{ }^{-} / \mathrm{NO}_{2}{ }^{-}$in coastal environments, in the following text, all $\mathrm{NO}_{3}{ }^{-} / \mathrm{NO}_{2}{ }^{-}$profiles obtained will be referred to as $\mathrm{NO}_{3}{ }^{-}$profiles.

All $\mathrm{O}_{2}$ and $\mathrm{NO}_{3}{ }^{-}$profiles were modeled using the program 'PROFILE' (Berg et al. 1998) to obtain estimates of net substrate consumption or production at all measured depths. Fick's second law of diffusion, including a production and consumption term, was used as the basis of the calculations. Porosity in the burrow wall was assumed to be equal to bulk sediment porosity. Steady-state conditions were assumed, as equilibrium between diffusion transport and reactions is attained within a few minutes at distances $<2 \mathrm{~mm}$.

Flux measurements. Total sediment metabolism was determined in September 2000 as $\mathrm{CO}_{2}$ and $\mathrm{O}_{2}$ flux across an inundated sediment-water interface using the closed-core technique (Kristensen et al. 1988), with 5 cores equipped with magnetic stirrers and driven by a central magnet. The cores were sealed by rubber stoppers and incubated for 2 to $4 \mathrm{~h}$ in darkness at $15^{\circ} \mathrm{C}$. Water samples for total $\mathrm{CO}_{2}\left(\mathrm{TCO}_{2}\right)$ and $\mathrm{O}_{2}$ measurement were taken before and after sealing the cores. The stirring rate was constantly below the resuspension level, and the $\mathrm{O}_{2}$ concentration of the headwater never dropped below $70 \%$ of air saturation. Samples for $\mathrm{TCO}_{2}$ were immediately preserved by addition of $10 \mu \mathrm{l}$ saturated $\mathrm{HgCl}_{2}$ solution $\mathrm{ml}^{-1}$ water sample and were later analyzed with the flow injection/diffusion cell technique (Hall \& Aller 1992). Samples for $\mathrm{O}_{2}$ determination were measured immediately after sampling with a Clark-type microelectrode (Revsbech 1989).

Sediment parameters. Separate cores for determination of sediment parameters were sliced into sections representing the 3 depths at which burrow profiles were obtained $(0-3,3-6$ and $6-9 \mathrm{~cm})$. Sediment density was determined as the weight of a known sediment volume, while sediment water content was determined as weight loss after drying sediment for $12 \mathrm{~h}$ at $105^{\circ} \mathrm{C}$.
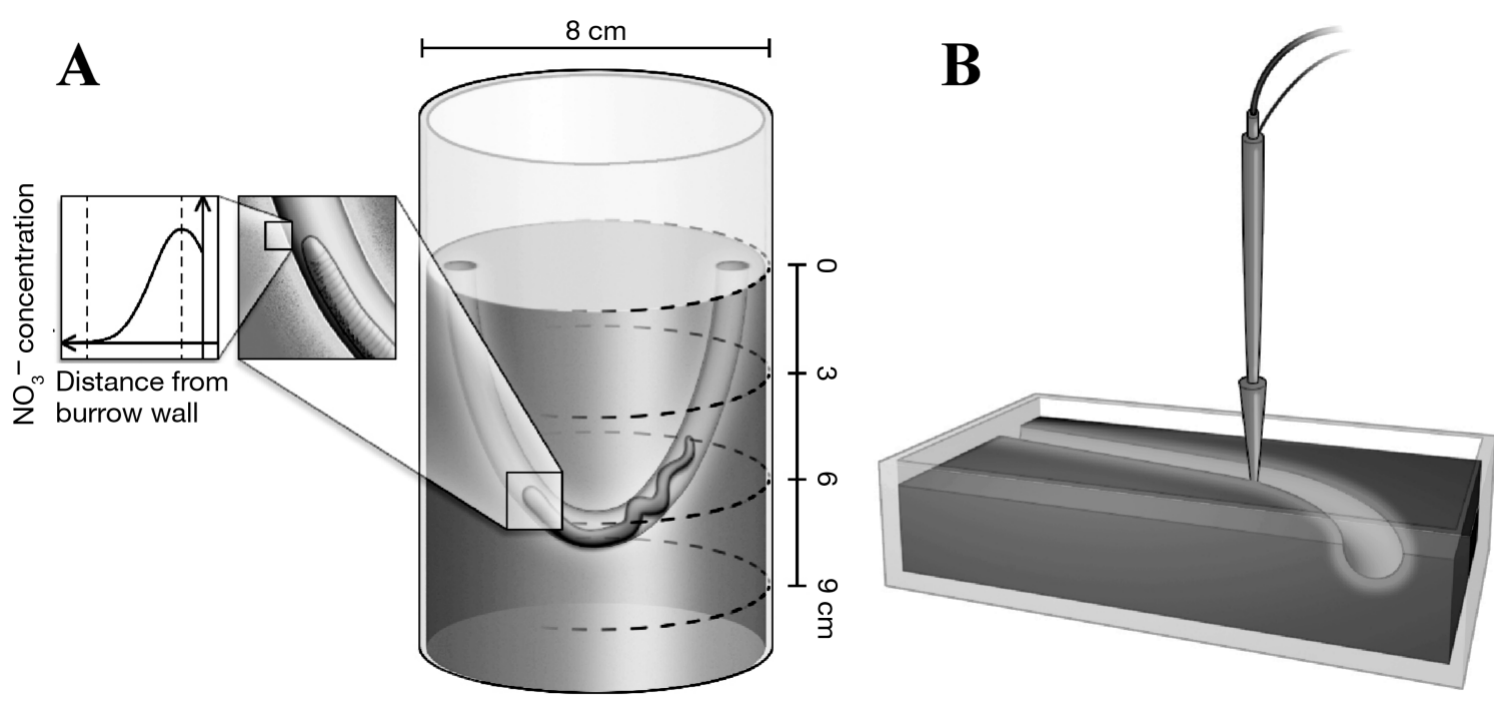

Fig. 1. Nereis diversicolor. Diagrams of burrows and sampling procedure. (A) Plexiglas core containing worm in its burrow and closeup of the burrow wall; sampling depths shown as intervals; diagram on left shows typical distribution of nitrate radial from burrow wall outward into the sediment obtained by micro-scale $\mathrm{NO}_{3}{ }^{-} / \mathrm{NO}_{2}{ }^{-}$biosensor; dashed lines represent outer limits of nitrification and denitrification zones. (B) Exposed burrow in plastic tray with micro-scale $\mathrm{NO}_{\mathrm{x}}$ biosensor inserted perpendicular to burrow wall 
Sediment from 10 sediment cores of known diameter was sieved through $1 \mathrm{~mm}$ mesh to obtain an estimate of Nereis diversicolor abundance. All worms were removed, counted, preserved in $4 \%$ formaldehyde, and later used for determination of individual dry weight (DW) as weight loss after drying for $12 \mathrm{~h}$ at $60^{\circ} \mathrm{C}$. Burrow length and diameter for the $N$. diversicolor population were calculated by applying individual (ind.) body DW/body wet weight (WW), body WW/burrow wall surface, and body WW/burrow volume correlations, as suggested by Kristensen (1984) and Vedel \& Riisgaard (1993). Since the relationships were originally made for $N$. virens, it was assumed that the closely related $N$. diversicolor and $N$. virens have identical body weight/burrow proportions.

\section{RESULTS}

\section{General observations}

Sediment from the sampling locality was muddy in appearance with an almost constant porosity with depth $\left(0.44\right.$ to $0.50 \mathrm{ml}$ pore water $\left.\mathrm{cm}^{-3}\right)$. Nitrate concentrations in the water overlying the sediment surface were $29.8 \mu \mathrm{M}$ in May 2000 and $4.5 \mu \mathrm{M}$ in September 2000. The sampling site was heavily bioturbated by Nereis diversicolor, which were present at a density of $2560 \pm 207$ ind. $\mathrm{m}^{-2}$ and a biomass of $27.6 \pm 5.2 \mathrm{~g} \mathrm{Dw}$ $\mathrm{m}^{-2}$. The size distribution was dominated by individuals of $<5 \mathrm{mgDw}(>50 \%)$. Average burrow diameter, burrow lengths, and total burrow wall surface were calculated as $1.96 \mathrm{~mm}, 14.0 \mathrm{~cm}$, and $2.3 \mathrm{~m}^{2}$ wall surface $\mathrm{m}^{-2}$ sediment surface, respectively.

\section{Sediment metabolism}

Sediment metabolism in September 2000, measured as $\mathrm{O}_{2}$ uptake, was $156 \pm 10.4 \mathrm{mmol} \mathrm{m}^{-2} \mathrm{~d}^{-1}(\mathrm{n}=5)$. The corresponding $\mathrm{TCO}_{2}$ release rate was $218 \pm 19.0 \mathrm{mmol}$ $\mathrm{m}^{-2} \mathrm{~d}^{-1}(\mathrm{n}=5)$, providing a respiratory quotient of 1.4 .

\section{$\mathrm{O}_{2}$ and $\mathrm{NO}_{3}^{-}$profiles}

Radial profiles of oxygen in May and September 2000 were all concave in shape due to active removal of oxygen by heterotrophic activity and reoxidation of reduced metabolites (Fig. 2). $\mathrm{O}_{2}$ disappeared rapidly and was below detection limit 0.90 to $1.30 \mathrm{~mm}$ into the burrow wall irrespective of depth, treatment or time (Table 1). Radial nitrate profiles from unamended and $\mathrm{NH}_{4}{ }^{+}$-enriched burrows showed a production zone close to the burrow wall with fairly pronounced sub- surface peaks, followed by a consumption zone in which nitrate rapidly declined to below the detection limit (Fig. 3A,B). This pattern was similar to the vertical nitrate profile obtained from the sediment surface layer (Fig. 3C). Addition of $\mathrm{NH}_{4}{ }^{+}$to the overlying water in May 2000 increased nitrate production rates in burrows, as indicated by a larger subsurface nitrate peak, but did not change the general shape of the profile (Fig. 3A). Although the $\mathrm{NO}_{3}{ }^{-}$level was substantially lower in September than May, the pattern of the profiles remained similar at all depths, with an $\mathrm{NO}_{3}^{-}$production zone adjacent to the burrow wall followed by an outer consumption zone (Fig. 3B). The radial $\mathrm{NO}_{3}{ }^{-}$ penetration depth did not change significantly with season or treatment $(p>0.05)$, and was not significantly different from vertical $\mathrm{NO}_{3}{ }^{-}$penetration into the sediment surface layer in September 2000 ( $p$ > 0.05). The zone of net nitrate production (indicated by the subsurface peaks of $\mathrm{NO}_{3}{ }^{-}$) closely followed oxygen penetration depth and was apparent to a depth of 0.94 to $1.48 \mathrm{~mm}$ zone into the burrow wall (Table 1). $\mathrm{NO}_{3}{ }^{-}$ was consumed by the sediment in a zone extending from the oxygen penetration boundary to the $\mathrm{NO}_{3}{ }^{-}$ detection boundary 2.01 to $2.58 \mathrm{~mm}$ into the sediment (Table 1), a zone 0.94 to $1.28 \mathrm{~mm}$ wide. The presence of acetylene blocked the nitrification reaction in the oxic zone, inducing subsurface $\mathrm{NO}_{3}{ }^{-}$production. The resulting profile indicates an almost linear diffusioncontrolled decrease in $\mathrm{NO}_{3}^{-}$concentration with increasing depth. Nitrate-reducing bacteria were not inhibited by the relatively low acetylene concentration in the pore water (20 Pa acetylene), and active nitrate uptake forced a concave curvature to the profile below the oxygen penetration depth.

Volume-specific rates of oxygen consumption, nitrification and nitrate reduction varied with depth in an irregular pattern within the respective production and consumption zones. For comparison, rates were depthintegrated and are presented as mean volume-specific rates for each production and consumption zone in the following text.

The mean volume-specific $\mathrm{O}_{2}$ consumption rates increased slightly from 10 to $14 \mu \mathrm{mol} \mathrm{cm} \mathrm{cm}^{-3} \mathrm{~d}^{-1}$ after $\mathrm{NH}_{4}{ }^{+}$addition in May (Table 2). Mean rates of oxygen consumption in $\mathrm{NH}_{4}{ }^{+}$-amended sediment were of comparable magnitude in May and September. However, rates appeared to vary down (i.e. along) the burrow, with the mean oxygen consumption rate at 3 to $6 \mathrm{~cm}$ depth significantly different from the rates at 0 to $3 \mathrm{~cm}$ and 6 to $9 \mathrm{~cm}$ depths $(\mathrm{p}<0.05)$. This difference is somewhat unexpected, as there were no down-burrow differences in $\mathrm{NO}_{3}{ }^{-}$production or $\mathrm{NO}_{3}{ }^{-}$consumption. The difference was most probably due to small-scale variability, but further investigation is needed to confirm this. 
Fig. 2. Steady-state radial $\mathrm{O}_{2}$ profiles around burrows of Nereis diversicolor. (A) Profiles from May 2000 for burrows submerged in seawater with or without (unamended) addition of $\mathrm{NH}_{4}^{+}$, showing mean $( \pm \mathrm{SE})$ measurements ( $=3$ and 9, respectively). (B) Measured burrow profiles from September 2000 for 3 sediment depths $(0-3,3-6$, and $6-9 \mathrm{~cm})(\mathrm{n}=12, \mathrm{n}=7$ and $\mathrm{n}=7$, respectively); all burrows were submerged in $\mathrm{NH}_{4}{ }^{+}$-amended seawater; curves represent best fit by 'PROFILE' modeling approach. In (A) and (B) shaded areas indicate distribution and magnitude of mean volume-specific $\mathrm{O}_{2}$ consumption and production rate estimates obtained from model fitting of the individual profiles; positive and negative values represent production and consumption, respectively

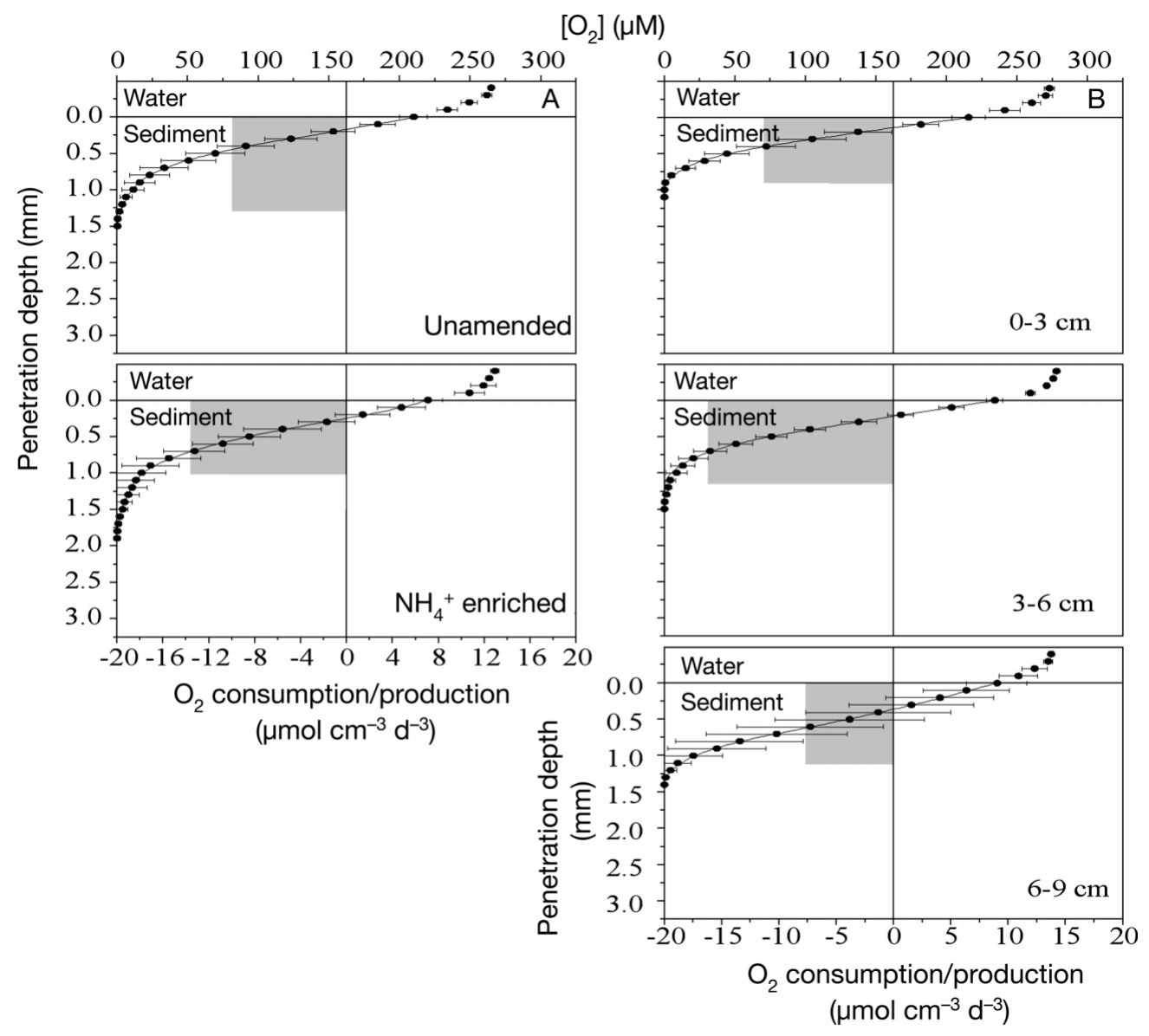

Nitrification appeared to be $\mathrm{NH}_{4}{ }^{+}$-limited in unamended burrow walls, as indicated by an increase in net nitrification from 674 to $2173 \mathrm{nmol} \mathrm{cm}^{-3} \mathrm{~d}^{-1}$ after $\mathrm{NH}_{4}{ }^{+}$addition in May (Table 2). Addition of acetylene effectively inhibited nitrification in the burrow wall, indicating that acetylene-inhibited bacteria mediated nitrate production in the oxic zone (Klemedtsson et al.
1988). The potential activity of nitrifying bacteria (when $\mathrm{NH}_{4}{ }^{+}$was added) generally decreased from May to September. Nitrification was so low in September that it could only be detected after addition of $\mathrm{NH}_{4}{ }^{+}$ (data not shown), and even then still exhibited relatively low rates of 182 to $721 \mathrm{nmol} \mathrm{cm} \mathrm{cm}^{-3} \mathrm{~d}^{-1}$. Burrow wall nitrification did not change significantly with

Table 1. Nereis diversicolor burrows. Radial penetration depths of oxygen, nitrate production, and nitrate from walls of burrows submerged in pure seawater, in seawater containing $100 \mu \mathrm{M} \mathrm{NH}_{4}{ }^{+}$, or $\mathrm{NH}_{4}{ }^{+}$-enriched seawater with added acetylene (May), and for burrows submerged in seawater containing $100 \mu \mathrm{M} \mathrm{NH}_{4}{ }^{+}$(September). Depths are means $( \pm \mathrm{SE})$ for all measured profiles. nd: no data

\begin{tabular}{|c|c|c|c|}
\hline & $\begin{array}{l}\mathrm{O}_{2} \text { penetration } \\
(\mathrm{mm})\end{array}$ & $\begin{array}{c}\mathrm{NO}_{3}{ }^{-} \text {production depth } \\
(\mathrm{mm})\end{array}$ & $\begin{array}{c}\mathrm{NO}_{3}{ }^{-} \text {penetration } \\
(\mathrm{mm})\end{array}$ \\
\hline \multicolumn{4}{|l|}{ May } \\
\hline$+0 \mu \mathrm{M} \mathrm{NH}_{4}^{+}$ & $1.30 \pm 0.30(\mathrm{n}=3)$ & $1.05 \pm 0.25(\mathrm{n}=3)$ & $2.58 \pm 0.22(\mathrm{n}=3)$ \\
\hline$+100 \mu \mathrm{M} \mathrm{NH}_{4}^{+}$ & $1.01 \pm 0.10(\mathrm{n}=9)$ & $1.20 \pm 0.11(\mathrm{n}=8)$ & $2.24 \pm 0.17(\mathrm{n}=8)$ \\
\hline$+100 \mu \mathrm{M} \mathrm{NH}_{4}{ }^{+}+$acetylene & nd & nd & $2.50 \pm 0.25(\mathrm{n}=2)$ \\
\hline \multicolumn{4}{|l|}{ September } \\
\hline Surface & nd & $1.23 \pm 0.65(\mathrm{n}=2)$ & $2.13 \pm 0.38(\mathrm{n}=2)$ \\
\hline $0-3 \mathrm{~cm}$ & $0.90 \pm 0.07(n=12)$ & $0.94 \pm 0.17(\mathrm{n}=12)$ & $2.01 \pm 0.18(\mathrm{n}=12$ \\
\hline $3-6 \mathrm{~cm}$ & $1.15 \pm 0.08(\mathrm{n}=7)$ & $1.48 \pm 0.21(\mathrm{n}=7)$ & $2.28 \pm 0.16(\mathrm{n}=7)$ \\
\hline $6-9 \mathrm{~cm}$ & $1.13 \pm 0.13(\mathrm{n}=7)$ & $1.14 \pm 0.25(\mathrm{n}=7)$ & $2.07 \pm 0.19(\mathrm{n}=7)$ \\
\hline
\end{tabular}




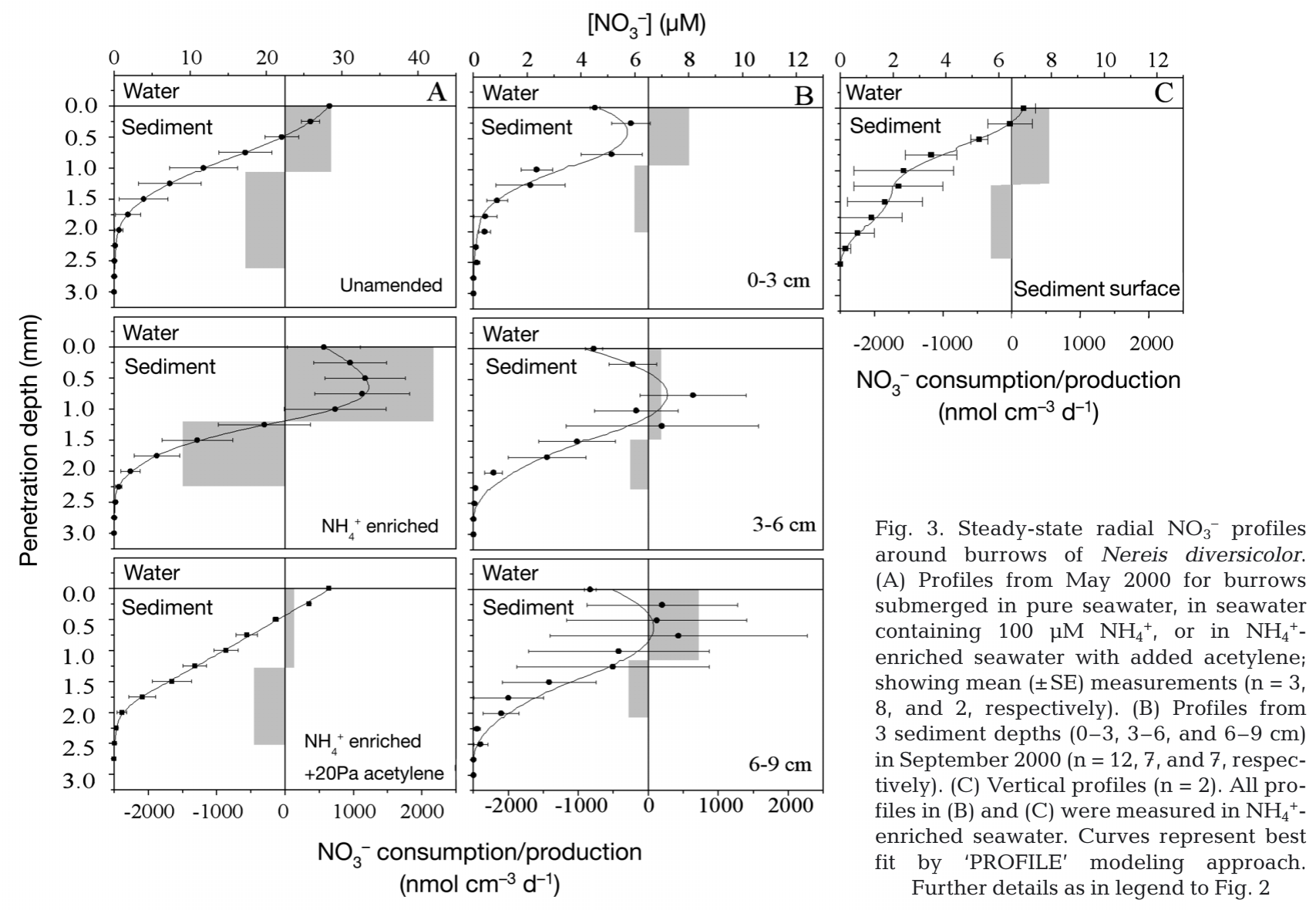

depth in the sediment $(p>0.05)$, with mean rates similar to those at the sediment surface.

Nitrate reduction increased from 579 to $1496 \mathrm{nmol}$ $\mathrm{cm}^{-3} \mathrm{~d}^{-1}$ in May after $\mathrm{NH}_{4}{ }^{+}$enrichment in response to the increased $\mathrm{NO}_{3}{ }^{-}$production (Table 2). The acetylene-amended burrows displayed nitrate reduction below the oxygen penetration depth at a rate of only

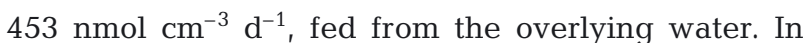
September, nitrate reduction was low at 194 to $284 \mathrm{nmol} \mathrm{cm}{ }^{-3} \mathrm{~d}^{-1}$, consistent with the low nitrification rates. Nitrate reduction in the surface sediment was

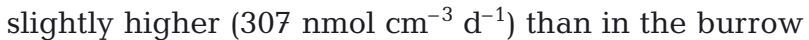
wall, although the difference was not significant $(\mathrm{p}>$ 0.05).

Table 2. Volume-specific rates of $\mathrm{O}_{2}$ consumption, nitrification, and nitrate reduction in sediment surrounding burrow walls of Nereis diversicolor for unamended, $100 \mu \mathrm{M} \mathrm{NH}_{4}{ }^{+}$-amended, and acetylene-amended treatments in May 2000, and for surface and burrow walls, both $100 \mathrm{MM} \mathrm{NH}_{4}{ }^{+}$-amended, in September 2000. Rates obtained from best-curve fits to measured oxygen and nitrate profiles. Value are mean $( \pm \mathrm{SE})$ for all measured profiles. nd: no data

\begin{tabular}{|c|c|c|c|}
\hline & $\begin{array}{l}\mathrm{O}_{2} \text { consumption } \\
\left(\mu \mathrm{mol} \mathrm{cm} \mathrm{cm}^{-3} \mathrm{~d}^{-1}\right)\end{array}$ & $\begin{array}{l}\text { Nitrification } \\
\left(\mathrm{nmol} \mathrm{cm}^{-3} \mathrm{~d}^{-1}\right)\end{array}$ & $\begin{array}{l}\text { Nitrate reduction } \\
\left(\mathrm{nmol} \mathrm{cm}^{-3} \mathrm{~d}^{-1}\right)\end{array}$ \\
\hline \multicolumn{4}{|l|}{ May } \\
\hline$+0 \mu \mathrm{M} \mathrm{NH}_{4}^{+}$ & $10.0 \pm 0.3(\mathrm{n}=3)$ & $674 \pm 246(\mathrm{n}=3)$ & $579 \pm 43(\mathrm{n}=3)$ \\
\hline$+100 \mathrm{\mu M} \mathrm{NH}_{4}^{+}$ & $13.6 \pm 0.5(\mathrm{n}=9)$ & $2173 \pm 354(\mathrm{n}=8)$ & $1496 \pm 122(\mathrm{n}=8)$ \\
\hline$+100 \mu \mathrm{M} \mathrm{NH}_{4}{ }^{+}+$acetylene & nd & & $453 \pm 129(\mathrm{n}=2)$ \\
\hline \multicolumn{4}{|l|}{ September } \\
\hline Surface $\left(+100 \mu \mathrm{M} \mathrm{NH}_{4}^{+}\right)$ & nd & $545 \pm 454(\mathrm{n}=2)$ & $307 \pm 52(\mathrm{n}=2)$ \\
\hline $0-3 \mathrm{~cm}\left(+100 \mu \mathrm{M} \mathrm{NH}_{4}^{+}\right)$ & $11.3 \pm 3.1(\mathrm{n}=4)$ & $588 \pm 267(\mathrm{n}=12)$ & $194 \pm 60(\mathrm{n}=13)$ \\
\hline $3-6 \mathrm{~cm}\left(+100 \mu \mathrm{M} \mathrm{NH}_{4}^{+}\right)$ & $16.2 \pm 2.6(\mathrm{n}=6)$ & $182 \pm 43(\mathrm{n}=7)$ & $260 \pm 79(\mathrm{n}=7)$ \\
\hline $6-9 \mathrm{~cm}\left(+100 \mu \mathrm{M} \mathrm{NH}_{4}^{+}\right)$ & $7.7 \pm 2.4(\mathrm{n}=4)$ & $721 \pm 290(\mathrm{n}=7)$ & $284 \pm 89(\mathrm{n}=8)$ \\
\hline
\end{tabular}




\section{DISCUSSION}

Burrow structures extend the oxic sediment-water interface, and thus oxic microbial respiration and bacterial nitrification/nitrate reduction, deep into the otherwise anoxic sediment (Kristensen 1984, Fenchel 1996). Previous attempts to localize nitrification/nitrate reduction zones around burrows have been made on a coarse scale involving disruption of the sediment (Kristensen et al. 1985), but by the use of microsensors (biosensors), nitrate profiles can be obtained at high spatial resolution with only limited disturbance of the sediment matrix, thus eliminating flaws introduced by sediment disrupture. The profiles obtained in the present study confirmed on a microscale the previous assumptions (Aller 1988) that the nitrification zone is restricted to the narrow oxygen-containing zone in the burrow wall being spatially separated from an outer nitrate-reducing zone.

The bulk nitrification rates estimated in this study are at the lower end of those normally observed in Danish shallow estuaries and coastal waters (Binnerup et al. 1992, Jensen et al. 1996, Hansen \& Kristensen 1998), but within the range of 0 to $1.8 \mathrm{mmol}$ $\mathrm{m}^{-2} \mathrm{~d}^{-1}$ measured by $\mathrm{NO}_{3}{ }^{-} / \mathrm{NO}_{2}{ }^{-}$sensors in another Danish fjord (Meyer et al. 2001). Only a few studies have measured nitrification rates in association with burrow structures (see Mayer et al. 1995 for review), and of these the majority report potential rates (slurry assays at high $\mathrm{NH}_{4}^{+}$concentrations) as opposed to measured rates. Only Aller (1988) has attempted to report actual rates. He estimated rates of 250 to $500 \mu \mathrm{M}$ pore water $\mathrm{d}^{-1}$ at $2.5^{\circ} \mathrm{C}(\sim 350$ to $700 \mathrm{nmol}$ $\mathrm{cm}^{-3}$ sediment $\mathrm{d}^{-1}$ at $15^{\circ} \mathrm{C}$ when corrected for temperature by $Q_{10} \sim 2.5$ : Hansen et al. 1981) by modeling nitrogen profiles around burrows of Nereis virens reported in Kristensen et al. (1985). These rates are very similar to those obtained by our biosensor measurements, despite differences in locality, spatial resolution, and techniques. Since modeled profiles only represent net rates, the possibility cannot be excluded that in both studies nitrification was underestimated due to nitrate reduction in the oxic zone. However, the results of acetylene addition proved that nitrate enters the sediment and passes the oxic zone via diffusion and that nitrate reduction is confined to the anoxic layers. Thus, our nitrification estimates, as well as those of Aller (1988), represent true rates, validating the use of biosensors and models for such estimates.

The 3-fold increase in nitrification rates after $\mathrm{NH}_{4}{ }^{+}$ enrichment is consistent with the general observation that only a fraction of the nitrification potential is utilized under natural conditions. The magnitude of the rates was also consistent with the potential rates of
1950 to $2600 \mathrm{nmol} \mathrm{cm}^{-3} \mathrm{~d}^{-1}$ found for Nereis virens burrows by Kristensen et al. (1985), but at the lower end of the broad range of rates (1000 to $10000 \mathrm{nmol}$ $\mathrm{cm}^{-3} \mathrm{~d}^{-1}$ ) reported for a variety of polychaete, bivalve and amphipod burrows (Mayer et al. 1995). Nereid burrows generally favor microbial activity such as nitrification through oxygen availability in a finegrained environment enrichment with $\mathrm{NH}_{4}{ }^{+}$from animal excreta and sedimentary metabolism (Kristensen 1985, Bartoli et al. 2000). However, in contrast to reports for most investigated macrofaunal species (Mayer et al. 1995), the nitrification potential of the burrow walls of $N$. virens did not exceed the activity at the sediment surface in our study. The cause for this discrepancy is not known, but as $\mathrm{NH}_{4}{ }^{+}$availability appears to regulate nitrification activity (Mayer et al. 1995), $\mathrm{O}_{2}$ and $\mathrm{NH}_{4}{ }^{+}$may have been in short supply in the burrow walls in our study.

The nitrate profiles clearly show that nitrate reduction occurred in a narrow ( 0.9 to $1.5 \mathrm{~mm}$ thick) zone outside the oxic-anoxic interface around burrows. The rates obtained are typical for marine surface sediment (Herbert 1999) and close to the potential denitrification rates in Nereis virens burrow walls measured by Kristensen et al. (1985). The enhanced nitrate reduction rates when nitrification was stimulated after addition of $\mathrm{NH}_{4}{ }^{+}$indicates that $\mathrm{NO}_{3}{ }^{-}$availability is rate-limiting in the burrow wall. A general $\mathrm{NO}_{3}^{-}$limitation of nitrate-reduction explains the similarity of potential nitrate-reducing activity in the burrow walls and at the sediment surface despite the fact that the burrow walls are rich in labile organic carbon from the mucus lining and thus are potential 'hot-spots' for heterotrophic activity.

The contribution of Nereis diversicolor burrows to bulk oxygen consumption, nitrification, and nitrate reduction can be estimated from the size distribution of the $N$. diversicolor population and by applying the 2D cylindrical reaction diffusion model of Aller (1988) to the volume-specific oxygen, nitrification, and nitrate reduction rates. Based on this model, it was estimated that $40 \%$ of the total $\mathrm{O}_{2}$ flux into the sediment occurred across the burrow wall surface (Table 3), showing that burrow walls are very important in bulk heterotrophic microbial activity of bioturbated sediments. The remaining $60 \%$ of the benthic oxygen consumption arose from oxygen flux across the sediment surface, animal uptake, and surface topography (Furukawa et al. 2000). Nitrification in the sediment surface and the burrow walls was a minor component in the total oxygen consumption, being responsible for about $4 \%$ of the total benthic oxygen consumption. Of the total nitrification, $77 \%$ occurred in the oxic burrow wall (Table 3); this is somewhat higher than previously reported contributions of 35 to 
Table 3. Diffusive $\mathrm{O}_{2}$ flux into sediment, nitrification and nitrate reduction rates in sediment inhabited by Nereis diversicolor population separated into burrow wall and surface contributions. Numbers in parentheses represent percentage contribution to bulk oxygen consumption, nitrification, and nitrate reduction by burrow walls. All estimates are for September 2000. nd: no data

\begin{tabular}{|c|c|c|c|}
\hline Compartment & $\begin{array}{c}\text { Diffusive } \\
\mathrm{O}_{2} \text { flux } \\
\left(\mathrm{mmol} \mathrm{m}^{-2} \mathrm{~d}^{-1}\right)\end{array}$ & $\begin{array}{c}\text { Nitrification } \\
\left(\mathrm{mmol} \mathrm{m}^{-2} \mathrm{~d}^{-1}\right)\end{array}$ & $\begin{array}{c}\text { Nitrate } \\
\text { reduction } \\
\left(\mathrm{mmol} \mathrm{m}^{-2} \mathrm{~d}^{-1}\right)\end{array}$ \\
\hline Surface & nd & 0.67 & 0.28 \\
\hline $\begin{array}{l}\text { Burrow walls } \\
\text { (100\% ventilation) }\end{array}$ & $61.1(40 \%)$ & $2.27(77 \%)$ & $1.28(82 \%)$ \\
\hline $\begin{array}{l}\text { Burrow walls } \\
\text { (30\% ventilation) }\end{array}$ & $18.3(12 \%)$ & $0.68(50 \%)$ & $0.38(58 \%)$ \\
\hline
\end{tabular}

$41 \%$ (Henriksen et al. 1980, Aller 1988, Kristensen et al. 1991). However, direct comparison of these values is not possible, as animal density, temperature, and oxygen penetration depths differed. Unfortunately, modeling of $\mathrm{NO}_{3}{ }^{-}$profiles does not provide an estimate of denitrification, since it represents net nitrate reduction, which does not discriminate denitrification from $\mathrm{NO}_{3}{ }^{-}$reduction to $\mathrm{NH}_{4}^{+}$via ammonification. Some studies have indicated that most of the reduced nitrate passes through the denitrification pathway (Binnerup et al. 1992, Pelegrí et al. 1994). However, other studies have shown that a large fraction of the $\mathrm{NO}_{3}{ }^{-}$may be reduced to ammonium in strongly reduced sediments with a surplus of electron donors (Christensen et al. 2000). The ratio of nitrate passing through the 2 pathways in sediment from Aggersund is not known. However, the sediment was heavily bioturbated and appeared relatively oxidized, indicating that denitrification was the main nitrate-reducing pathway driving the profiles. Thus, our estimates of $\mathrm{NO}_{3}{ }^{-}$reduction provide a maximum measure of denitrification. Under these assumptions, it was estimated that denitrification only contributed $0.9 \%$ of the total $\mathrm{TCO}_{2}$ release $\left(\mathrm{COH}: \mathrm{NO}_{3}{ }^{-}\right.$stoichiometry of 1.25$)$, and hence is of only minor importance in carbon oxidation. Nevertheless, this process is very important in nitrogen cycling and acts as a significant sink for combined nitrogen. The burrow walls of $N$. diversicolor increase the nitrate-reducing sediment volume more than 3 -fold and account for $82 \%$ of bulk nitrate reduction (Table 3), indicating that $N$. diversicolor burrows are the most important structure for nitrogen cycling in the sediment. Our use of pore water profiles for biogeochemical budgets can only be crude estimates, as the calculations are based on measurements made under optimized conditions and assuming that the measured oxygen and nitrate penetrations depths represent the true in situ conditions, that rates are uniform in all layers, and that nitrate concentrations in the overlying water are constant through time. However, nitrate and oxygen concentrations fluctuate in the burrow lumen as a consequence of the intermittent irrigation patterns of $N$. diversicolor, and may rapidly decrease during periods of rest (Kristensen et al. 1991). Due to these flaws, the calculated importance of burrow structures for total sediment oxygen uptake and nitrification/denitrification are probably overestimated. As $N$. diversicolor is known to ventilate its burrow approximately $30 \%$ of the time under natural conditions (Vedel et al. 1994), the estimated burrow wall contributions to bulk nitrification and nitrate reduction may not exceed 50, and 58\%, respectively. These levels are similar to previous estimates of 35 to $41 \%$ for nitrification and 62 to $79 \%$ for denitrification for other bioturbated sediments (Henriksen et al. 1980, Aller 1988, Kristensen et al. 1991, Binnerup et al. 1992, Pelegrí et al. 1994). Animal and community densities also changes with season and sediment type under natural conditions. This also may affect the relative importance of nitrification and nitrate reduction pathways. Nevertheless bioturbation is undoubtedly very important for nitrogen cycling through the simultaneous stimulation of nitrification and nitrate reduction in sediments.

In conclusion, our data demonstrate that nondestructive micro-biosensors are a highly useful tool for determining fine-scale distributions of $\mathrm{O}_{2}$ and $\mathrm{NO}_{3}{ }^{-}$ in bioturbated sediments, and thus for locating zones involved in oxic respiration, nitrification, and nitrate reduction. The profiles obtained showed that bioturbation by Nereis diversicolor greatly affected sediment oxygen uptake, nitrification, and nitrate reduction by extending the sediment-water interface deep into otherwise anoxic sediment. Due to the intermittent irrigation patterns of $N$. diversicolor, nitrification and nitrate reduction contribute less to the overall nitrogen cycling than predicted from a simple extension of the surface area. However, it is clear that the presence of $N$. diversicolor has a large impact on sediment nitrogen cycling and accelerates the removal of bioavalable nitrogen through the simultaneous stimulation of nitrification and nitrate reduction.

Acknowledgements. We would like to acknowledge the assistance of the technical staff at the Department of Microbial Ecology, The University of Aarhus, and to thank Lars Peter Nielsen, University of Aarhus, for valuable comments. This study was partially funded by Raadet for Ulandsforskning (DANIDA) (Ref. No. 90884) and by the ISLED Contract ENV4CT97-0582 (ELOISE contribution number 404/17). 


\section{LITERATURE CITED}

Aller RC (1988). Benthic fauna and biogeochemical processes in marine sediments: the role of burrow structures. In: Blackburn TH, Sørensen J (eds) Nitrogen cycling in coastal marine environments. John Wiley \& Sons, Chichester, p 301-338

Bartoli M, Nizzoli D, Welsh DT, Viaroli P (2000) Short-term influence of recolonisation by the polychaete worm Nereis succinea on oxygen and nitrogen fluxes and denitrification: a microcosm simulation. Hydrobiologia 431:165-174

Berg P, Risgaard-Petersen N, Rysgaard S (1998) Interpretation of measured concentration profiles in sediment pore water. Limnol Oceanogr 43:1500-1510

Binnerup SJ, Jensen K, Revsbech NP, Jensen MH, Sørensen J (1992) Denitrification, dissimilatory reduction of nitrate to ammonium, and nitrification in a bioturbated estuarine sediment as measured with ${ }^{15} \mathrm{~N}$ and microsensor techniques. Appl Environ Microbiol 58:303-313

Christensen PB, Rysgaard S, Sloth NP, Dalsgaard T, Schwaerter S (2000) Sediment mineralization, nutrient fluxes, denitrification and dissimilatory nitrate reduction to ammonium in an estuarine fjord with sea cage trout farms. Aquat Microb Ecol 21:73-84

Fenchel T (1996) Worm burrows and oxic microniches in marine sediments. 1. Spatial and temporal scales. Mar Biol 127:289-295

Furukawa Y, Bentley SJ, Shiller AM, Lavoie DW, van Cappellen P (2000) The role of biologically-enhanced pore water transport in early diagenesis: an example from carbonate sediments in the vicinity of North Key Harbor, Dry Tortugas National Park, Florida. J Mar Res 58:493-522

Gilbert F, Stora G, Bonin P (1998) Influence of bioturbation on denitification activity in Mediterranean coastal sediments: an in situ experimental approach. Mar Ecol Prog Ser 163: 99-107

Gribsholt B, Kostka JE, Kristensen E (2003) Impact of fiddler crabs and plant roots on sediment biogeochemistry in a Georgia salt marsh. Mar Ecol Prog Ser 259:237-251

Hall POJ, Aller RC (1992) Rapid, small-volume flow injection analysis for $\mathrm{\Sigma CO}_{2}$ and $\mathrm{NH}_{4}{ }^{+}$in marine and freshwaters. Limnol Oceanogr 37:1113-1118

Hansen JI, Henriksen K, Blackburn TH (1981) Seasonal distribution of nitrifying bacteria and rate of nitrification in coastal marine sediments. Microb Ecol 7:297-304

Hansen K, Kristensen E (1998) The impact of the polychaete Nereis diversicolor and enrichment with macroalgal (Chaetomorpha Linum) detritus on benthic metabolism and nutrient dynamics in organic-poor and organic-rich sediment. J Exp Mar Biol Ecol 231:201-223

Hansen K, King GM, Kristensen E (1996) Impact of the softshell clam Mya arenaria on sulfate reduction in an intertidal sediment. Aquat Microb Ecol 10:181-194

Henriksen K, Hansen JI, Blackburn TH (1980) The influence of benthic infauna on exchange rates of inorganic nitrogen between sediment and water. Ophelia Suppl 1:249-256

Herbert RA (1999) Nitrogen cycling in coastal marine ecosystems. FEMS Microbiol Rev 23:563-590

Jensen K, Revsbech NP, Nielsen LP (1993) Microscale distribution of nitrification activity in sediment determined with a shielded microsensor for nitrate. Appl Environ Microbiol 35:853-857

Jensen KM, Jensen MH, Kristensen E (1996) Nitrification and denitrification in Wadden Sea sediments (Königshafen, Island of Sylt, Germany) as measured by nitrogen isotope pairing and isotope dilution. Aquat Microb Ecol 11: 181-191
Klemedtsson L, Svensson BH, Rosswall T (1988) A method of selective inhibition to distinguish between nitrification and denitrification as source of nitrous oxide in soil. Biol Fertil Soils 6:112-119

Koike I, Hattori A (1978) Simultaneous determination of nitrification and nitrate reduction in coastal sediments by an ${ }^{15} \mathrm{~N}$ dilution technique. Appl Environ Microbiol 35: 853-857

Kristensen E (1984) Effect of natural concentrations on nutrient exchange between a polychaete burrow in estuarine sediment and the overlying water. J Exp Mar Biol Ecol 75: 171-190

Kristensen E (1985) Oxygen and inorganic nitrogen exchange in a Neries virens (Polychaeta) bioturbated sedimentwater system. J Coast Res 1:109-116

Kristensen E (1988) Benthic fauna and biogeochemical processes in marine sediments: Microbial activities and fluxes. In: Blackburn TH, Sørensen J (eds) Nitrogen cycling in coastal marine environments. John Wiley \& Sons, Chichester, p 275-299

Kristensen E, Jensen MH, Andersen TK (1985) The impact of polychaete (Nereis virens Sars) burrows on nitrification and nitrate reduction in estuarine sediments. J Exp Mar Biol Ecol 85:75-91

Kristensen E, Andersen FØ, Kofoed LH (1988) Preliminary assessment of benthic community metabolism in a southeast Asian mangrove swamp. Mar Ecol Prog Ser 48: 137-145

Kristensen E, Jensen MH, Aller RC (1991) Direct measurement of dissolved inorganic nitrogen exchange and denitrification in individual polychaete (Neries virens) burrows. J Mar Res 49:355-377

Larsen LH, Kjær T, Revsbech NP (1997) A microscale $\mathrm{NO}_{3}^{-}$ biosensor for environmental applications. Anal Chem 69: 3527-3531

Lomstein BA, Jensen AU, Hansen JW, Andreasen JB, Hansen LS, Berntsen J, Kunzendorf H (1998) Budgets of sediment nitrogen and carbon cycling in the shallow water of Knebel Vig, Denmark. Aquat Microb Ecol 14:69-80

Lorenzen J, Larsen LH, Kjær T, Revsbech NP (1998) Biosensor determination of the microscale distribution of nitrate, nitrate assimilation, nitrification, and denitrification in a diatom-inhabited freshwater sediment. Appl Environ Microbiol 64:3264-3269

Mayer MS, Schaffner L, Kemp WM (1995) Nitrification potentials of benthic macrofaunal tubes and burrow walls: effects of sediment $\mathrm{NH}_{4}{ }^{+}$and animal irrigation behavior. Mar Ecol Prog Ser 121:157-169

Meyer RL, Kjær T, Revsbech NP (2001) Use of $\mathrm{NO}_{\mathrm{x}}^{-}$microsensors to estimate the activity of sediment nitrification and $\mathrm{NO}_{\mathrm{x}}{ }^{-}$consumption along an estuarine salinity, nitrate, and light gradient. Aquat Microb Ecol 26:181-193

Nielsen LP (1992) Denitrification in sediment determined from nitrogen isotope pairing. FEMS Microbiol Ecol 86: 357-362

Nielsen OI, Kristensen E, Holmer M (2003) Impact of Arenicola marina (Polychaeta) on sediment sulfur dynamics in Aquat Microb Ecol 33:95-105

Ormeland RS, Capone DG (1988) Use of 'specific' inhibitors in biogeochemistry and microbial ecology. In: Marshall KC (ed) Advances in microbial ecology, Vol 10. Plenum Publishing Corporation, New York, p 285-383

Pelegrí SP, Blackburn H (1995) Effect of bioturbation by Nereis sp., Mya arenaria and Cerastoderma sp. on nitrification and denitrification in estuarine sediments. Ophelia 42:289-299

Pelegrí SP, Nielsen LP, Blackburn H (1994) Denitrification in 
estuarine sediment stimulated by the irrigation activity of the amphipod Corophium volutator. Mar Ecol Prog Ser 105:285-290

Phillips TM, Lovell CR (1999) Distributions of total and active bacteria in biofilms lining tubes of the onuphid polychaete Diopatra cuprea. Mar Ecol Prog Ser 183:169-178

Reichardt W (1988) Impact of bioturbation by Arenicola marina on microbiological parameters in intertidal sediments. Mar Ecol Prog Ser 44:149-158

Revsbech NP (1989) An oxygen electrode with a guard cathode. Limnol Oceanogr 28:474-478

Editorial responsibility: Bess Ward,

Princeton, New Jersey, USA
Svensson JM, Leonardson L (1996) Effects of bioturbation by tube-dweelling chironomid larvae on oxygen uptake and denitrification in eutrophic lake sediments. Freshw Biol 35:289-300

Vedel A, Riisgård HU (1993) Filter-feeding in the polychaete Nereis diversicolor: growth and bioenergetics. Mar Ecol Prog Ser 100:145-152

Vedel A, Andersen BB, Riisgård HU (1994) Field investigations of pumping activity of the facultative filter-feeding polychaete Nereis diversicolor using an improved infrared phototransducer system. Mar Ecol Prog Ser 103:91-101

Submitted: January 12, 2003; Accepted: August 19, 2003 Proofs received from author(s): November 14, 2003 